Article

\title{
Screening Criteria and Considerations of Offshore Enhanced Oil Recovery
}

\author{
Pan-Sang Kang ${ }^{1, \dagger}{ }^{\dagger}$ Jong-Se Lim ${ }^{1, *}$ and Chun Huh ${ }^{2, \dagger}$ \\ Received: 17 December 2015; Accepted: 8 January 2016; Published: 14 January 2016 \\ Academic Editor: Susan Krumdieck \\ 1 Department of Energy and Resources Engineering, Korea Maritime and Ocean University, Yeongdo-Gu, \\ Busan 49112, Korea; pskang@kmou.ac.kr \\ 2 Department of Petroleum and Geosystems Engineering, The University of Texas at Austin, Austin, \\ TX 78712-1585, USA; chunhuh@mail.utexas.edu \\ * Correspondence: jslim@kmou.ac.kr; Tel.: +82-51-410-4682 \\ + These authors contributed equally to this work.
}

\begin{abstract}
The application of enhanced oil recovery (EOR) in offshore oil fields has received significant attention due to the potentially enormous amount of recoverable oil. However, EOR application offshore is in its very early stage due to conditions that are more complex than onshore oil fields, owing to the unique parameters present offshore. Therefore, successful EOR applications in offshore oil fields require different screening criteria than those for conventional onshore applications. A comprehensive database for onshore applications of EOR processes together with a limited offshore EOR application database are analyzed in this paper, and the important parameters for successful offshore application are incorporated into the new EOR screening criteria. In this paper, screening criteria to determine acceptable EOR processes for offshore fields, including hydrocarbon gas miscible, $\mathrm{CO}_{2}$ miscible, and polymer processes, are presented. Suggested screening criteria for these EOR processes comprise quantitative boundaries and qualitative considerations. Quantitative screening criteria are predominantly based on quantifiable data, such as oil and reservoir properties. Qualitative screening considerations mainly focus on the operational issues present offshore, including platform space constraints, limited disposal options, injectant availability, and flow assurance matters (including hydrate formation and difficulties in emulsion separation).
\end{abstract}

Keywords: enhanced oil recovery; offshore; EOR screening

\section{Introduction}

Korea is globally renowned for its proven and established shipbuilding technology and construction of offshore oilfield development facilities. However, Korean shipbuilding companies are now eagerly seeking new market opportunities to overcome increasing competition, and are investing significant resources in the research and development of offshore oilfield production technologies, such as enhanced oil recovery (EOR) processes: the research presented here arises from this trend.

While oil production from most oil fields worldwide is rapidly declining, discovering new oil fields is extremely difficult. Primary and secondary recoveries, from methods such as water flooding, typically extract no more than $10 \%$ to $40 \%$ of the original-oil-in-place (OOIP). This leaves a huge amount of potentially producible oil remaining in known reservoirs. EOR processes involve oil recovery by the injection of substances not normally present in the reservoir [1] and are designed to increase oil recovery and extend the productive life of an oil field; various EOR processes have been effectively applied. As most EOR projects are initially capital-intensive and high risk, appropriate EOR process selection for the target oil field is crucial. Inappropriate EOR methods must be identified 
and dismissed in the early stages, before detailed feasibility studies of possible EOR processes have taken place.

Most EOR methods, and hence most EOR screening criteria, have focused on onshore field application, owing to the relatively low cost, risk, complexity, and high injectant availability compared with offshore field application. Several studies have revealed offshore challenges for EOR application [2-8]. The remote location of offshore fields leads to higher transportation costs for injectants from onshore. There are limited disposal options for wastes such as produced water with chemicals or stable emulsions, which are very difficult to separate from produced oils, caused by EOR application. Wastes transportation by ship to onshore processing facilities can be an unacceptable option if the amount is huge. Waste disposal at sea is one option, but there are strict regulations protecting the sea environment. In the case of gas disposal, flaring is a relatively easy disposal process, but there are operational and $\mathrm{HSE}$ issues if $\mathrm{CO}_{2}$ concentration in the produced gas is high. Some injectants require special care and the distance from the shore causes difficulties in quality control of the injectant. High well costs lead to large well spacings (a typical well spacing for offshore fields is approximately $1 \mathrm{~km}$ ) associated with large uncertainties in reservoir characterization, well patterns that are far from ideal, a longer interval before the EOR response can be observed, and a limited number of wells for injection and disposal. Space and weight limits on the platform cause difficulty in installing processing facilities for EOR applications, and in storing injection and produced fluids. Some EOR processes exacerbate flow assurance issues such as hydrate formation and highly stable emulsion generation. Flow assurance issues are common in offshore but only issues relating to each EOR process were put into each EOR screening consideration.

Despite these challenges, EOR application in offshore oil fields is receiving significant attention. The size of the targeted offshore oil fields is generally large, because their OOIP had to be sufficiently large to overcome the high cost of offshore oil development. This means that a large amount of oil could potentially be recovered using EOR. These considerations make offshore EOR application a promising option for offshore fields with decreasing oil production. Figure 1 [9-23] shows that the number of successful EOR applications in offshore fields has been steadily increasing. In our database, there are total 456 cases of successful EOR applications (onshore: 437, offshore: 19). Considering that the application of EOR techniques in offshore fields is at an early stage of development and shows high potential, screening criteria that are more representative of the specific offshore conditions than the conventional onshore screening criteria are needed. Most previously suggested screening criteria provide ranges of reservoir and oil properties for excluding inappropriate EOR process. Recently, several authors have implemented EOR feasibility studies with operational issues [24-26] because EOR applications closely relate with operational conditions. For setting screening processes of offshore EOR applications, operational issues need to be considered because there are high possibilities of operational problem occurrences induced by EOR applications in complex offshore environments.

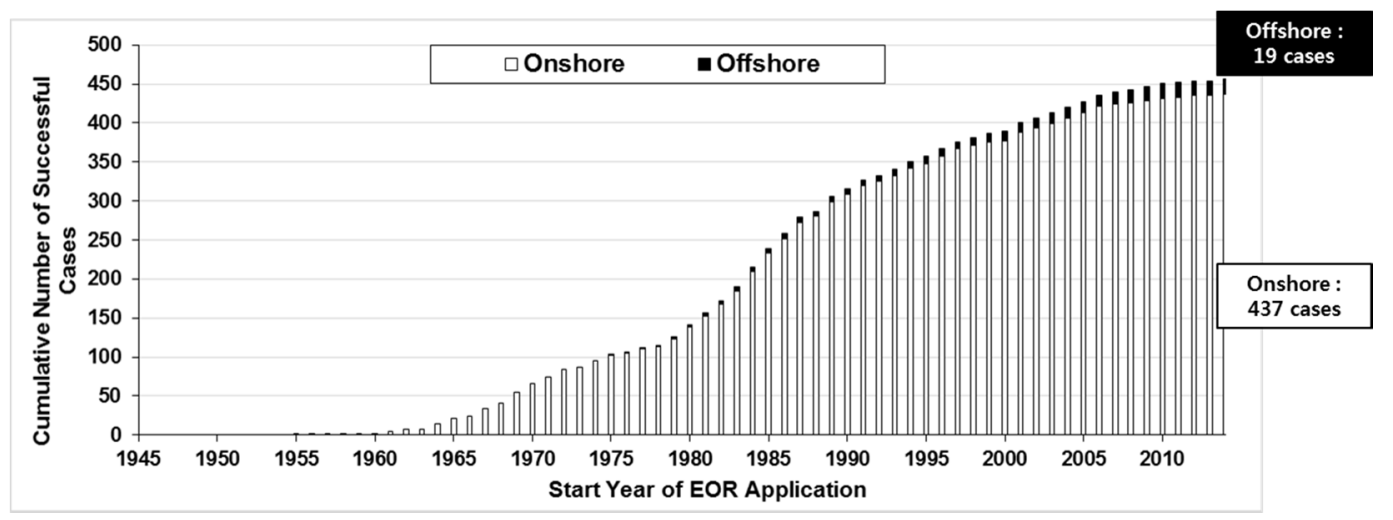

Figure 1. Cumulative number of successful cases of EOR application by start year [9-23]. 
This paper analyzes cases of successful EOR for onshore and offshore applications. New technical screening criteria for offshore EOR applications are proposed, based on a comprehensive analysis of field cases. Screening criteria for offshore EOR applications in this study comprise quantitative bounds imposed on oil and reservoir properties; and qualitative constraints including injectant availability, flow-assurance facility issues, and HSE issues arising for EOR applications offshore. This paper is focused on EOR application in deep water offshore rather than the shallow water shelf.

\section{Data Collection}

Previously, our research group developed an EOR screening method applying an artificial neural network algorithm to the database of EOR application cases [27]. This database, with an update of recently-published EOR cases, was used to develop screening criteria in this study. Figure 2 summarizes the data collection and processing procedure for EOR application cases. For quantitative screening criteria, EOR application data from onshore oil fields (oil fields in lakes or rivers were classified as onshore oil fields) are generally extracted from a series of worldwide EOR surveys on successfully producing or completed EOR projects [9-18]. After this data-filtering process, described in Figure 2, 437 successful cases of onshore EOR application were used for analysis.

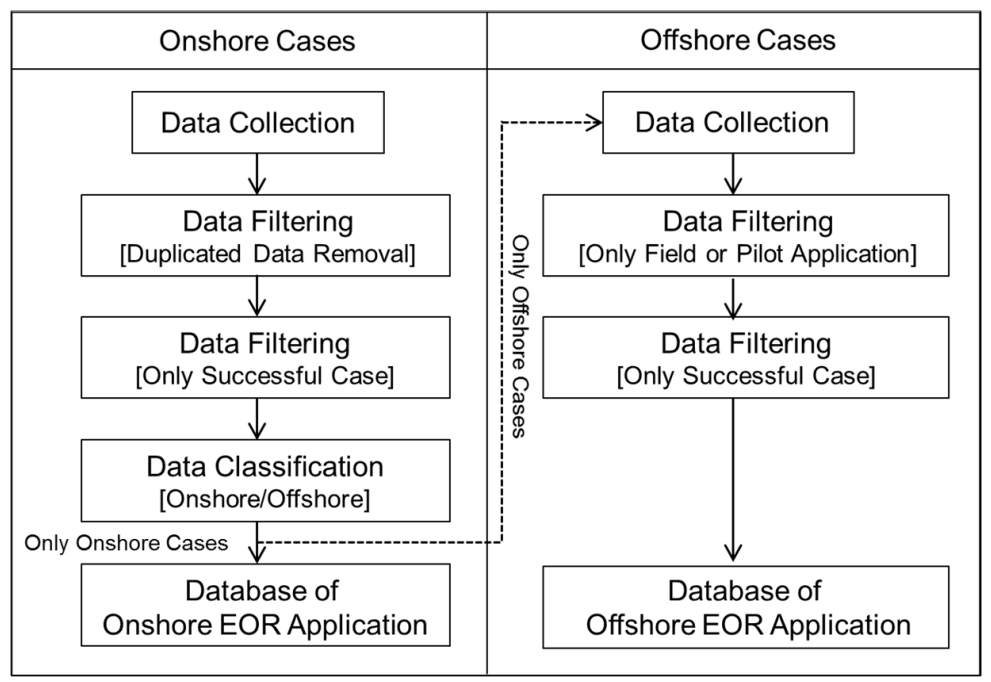

Figure 2. Procedure for data collection of EOR application cases.

Table 1 shows the EOR cases in offshore fields gathered for this study by our literature survey. After data filtering, 19 successful field and pilot cases in offshore environment were used for analysis. For pilot cases in offshore fields, only cases where EOR fluid was injected into the reservoir for enhanced oil recovery were considered; single-well tracer tests or feasibility test cases were not included for setting screening criteria but their consideration were applied to setting screening considerations.

Most available data were given in ranges, and averaged values were used for analysis when setting screening criteria in this study, since we deemed outlying values unrepresentative of reservoir properties for screening purposes. For example, maximum permeability values for some fields are higher than 15,000 md (millidarcy) owing to fractures, which may lead to unrealistic EOR screening. For quantitative screening criteria, unsuccessful cases were not used because some failures of EOR applications are related to economic and political issues, the decision-making process, and compatibility with vicinal oil field projects. Hence, we deemed that EOR failures may not directly contribute to understanding the technical aspects of EOR screening. 
Table 1. Successful enhanced oil recovery (EOR) application cases in offshore fields.

\begin{tabular}{|c|c|c|c|c|c|}
\hline Type & Field & Location & Start Year of EOR Application & Project Scale & References \\
\hline \multicolumn{6}{|c|}{ Hydrocarbon (HC) Gas Injection } \\
\hline \multirow{9}{*}{ miscible gas } & Ekofisk & North Sea & 1975 & field & \multirow{4}{*}{ [20] } \\
\hline & Beryl & North Sea & 1977 & field & \\
\hline & Statfjord & North Sea & 1979 & field & \\
\hline & Brent & North Sea & 1981 & field & \\
\hline & South Pass Block 89 & Gulf of Mexico & 1983 & field & \multirow{3}{*}{ [18] } \\
\hline & Ula & North Sea & 1986 & field & \\
\hline & South Pass Block 89 & Gulf of Mexico & 1989 & field & \\
\hline & Alwyn North & North Sea & 1999 & field & \multirow{2}{*}{ [20] } \\
\hline & Smorbukk South & North Sea & 1999 & field & \\
\hline \multirow{4}{*}{ miscible WAG } & Snorre (SnA) & North Sea & 1994 & field & \multirow{4}{*}{$\begin{array}{l}{[20]} \\
{[23]} \\
{[20]}\end{array}$} \\
\hline & South Bae & North Sea & 1994 & field & \\
\hline & Ula & North Sea & 1998 & field & \\
\hline & Magnus & North Sea & 2002 & field & \\
\hline \multicolumn{6}{|c|}{ Polymer Injection } \\
\hline polymer & SZ36-1 & Bohai & 2003 & pilot & \multirow[t]{2}{*}{ [19] } \\
\hline polymer & PF-B & Bohai & 2006 & pilot & \\
\hline polymer & PF-C & Bohai & 2007 & pilot & \multirow{2}{*}{ [21] } \\
\hline polymer & PF-A & Bohai & 2008 & pilot & \\
\hline polymer & Captain & North Sea & - & pilot & - \\
\hline \multicolumn{6}{|c|}{ Steam Injection } \\
\hline cyclic steam & - & Bohai & 2009 & pilot & [22] \\
\hline
\end{tabular}

Figure 3 summarizes all of the filtered EOR cases, both onshore and offshore, according to the different EOR processes employed. For onshore fields, thermal EOR processes (mainly steam injection, but also hot water injection and in situ combustion) are the most common EOR applications, followed by $\mathrm{CO}_{2}$ miscible, hydrocarbon (HC) gas miscible, and polymer processes. In contrast, the HC gas miscible process is the most commonly applied EOR method in offshore fields. Since EOR mechanisms are the same in onshore and offshore fields, there are unique governing parameters for offshore applications. Considering these parameters in addition to the qualitative analysis of the above database, the screening criteria for $\mathrm{HC}$ gas miscible, $\mathrm{CO}_{2}$ miscible, and polymer processes were developed as described in detail below.

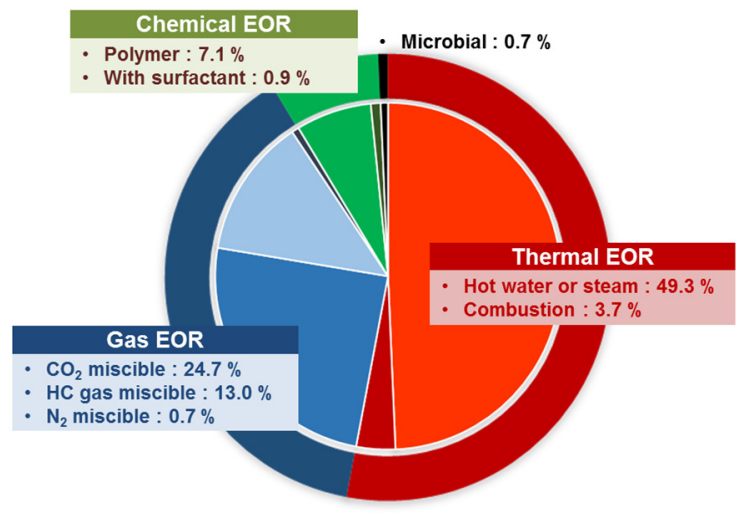

(a)

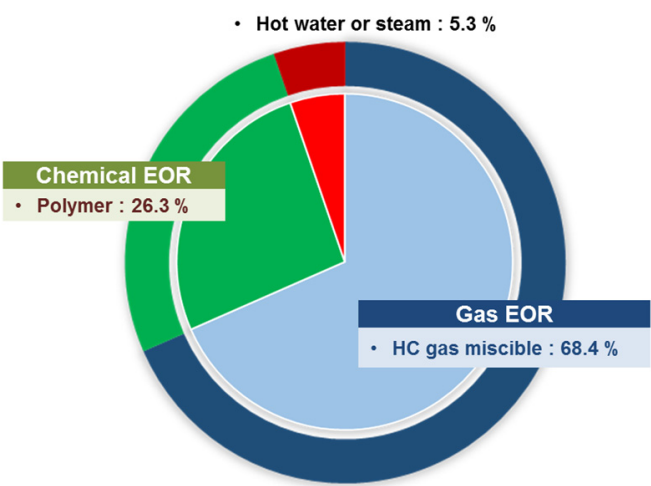

(b)

Figure 3. Successful EOR cases in onshore and offshore fields. (a) Onshore cases; (b) Offshore cases.

\section{Hydrocarbon (HC) Gas Miscible Process}

For offshore fields, $\mathrm{HC}$ gas injection is the most commonly applied EOR process, as shown in Figure 3. This is because HC gas availability is higher than other EOR injectants in the offshore environment. HC gas for injection can be supplied by produced gas from the reservoir or nearby wells, or transported from onshore. HC gas is commonly produced from the reservoir, although 
HC gas production highly depends on the depositional environment and hydrocarbon composition. Considering the transportation cost, produced HC gas is generally the best option for injection, but produced gas needs to be processed in some cases for miscibility achievement or meeting compatibility with injection facilities. In addition to the effectiveness of the HC gas miscible process in improving oil recovery, the limited platform space favors the reinjection of produced gas into the reservoir, unless the economical scale of HC gas is available. Major challenges associated with gas injection include gas fingering and channeling due to the low viscosity and density of gas compared to oil, and reservoir heterogeneity. To mitigate these problems, gas is commonly injected in the form of WAG, which provides better sweep efficiency and reduces gas channeling from injector to producer.

\subsection{Data Analysis}

Table 2 shows the previously suggested screening criteria for the HC gas miscible method. These criteria have focused on onshore EOR. For considering the offshore environment and setting screening criteria, screening parameters in Table 2 are analyzed selectively.

Table 2. Previously-suggested screening criteria for HC gas miscible applications.

\begin{tabular}{|c|c|c|c|c|c|}
\hline Parameters & Reference [28] & Reference [29] & Reference [30] & Reference [31] & Reference [32] \\
\hline Oil viscosity $(\mathrm{cP})$ & $<20$ & $<10$ & $<3$ & $<5$ & $<3$ \\
\hline Oil gravity $(\mathrm{cP})$ & $>26$ & $>35$ & $>23$ & $>24$ & $>23$ \\
\hline Oil composition & - & $\begin{array}{l}\text { high \% of light } \\
\text { hydrocarbon }\end{array}$ & $\begin{array}{l}\text { high \% of light } \\
\text { hydrocarbon }\end{array}$ & - & $\begin{array}{l}\text { high \% of light } \\
\text { hydrocarbon }\end{array}$ \\
\hline Oil saturation (\%) & $>25$ & $>30$ & $>30$ & $>30$ & $>30$ \\
\hline Depth $(\mathrm{ft})$ & - & - & $>4000$ & $>3937$ & $>4000$ \\
\hline Permeability & homogeneous & - & homogeneous & - & - \\
\hline Net thickness & $\begin{array}{l}\text { thin, dipping } \\
\text { preferred }\end{array}$ & $\begin{array}{l}\text { thin unless } \\
\text { dipping }\end{array}$ & $\begin{array}{l}\text { thin unless } \\
\text { dipping }\end{array}$ & - & $\begin{array}{l}\text { thin unless } \\
\text { dipping }\end{array}$ \\
\hline Reservoir pressure (psi) & $>1500$ & - & - & - & >MMP \\
\hline Gas cap & - & - & - & no & - \\
\hline
\end{tabular}

MMP: Minimum Miscible Pressure.

Depth is not quantitatively analyzed for screening criteria for offshore applications. Depth relates to reservoir pressure for miscible conditions; however, water depth must be considered in offshore fields. Reservoir pressure and oil composition mainly influence miscibility in the reservoir and they are important parameters in assessing the effectiveness of miscible gas EOR processes. As production progresses, they change and affect miscibility in the reservoir. These parameters need to be monitored in the field. Owing to the lack of data, pressure data was not provided in this research. Considering the high uncertainty in the reservoir characterization of offshore fields, reservoir heterogeneity was not considered for screening criteria. Generally, the presence of a gas cap is unfavorable, although the HC gas miscible application in Brent field, which has a primary gas cap, was successful. As there is some uncertainty as to whether the presence of a gas cap is an appropriate parameter for early EOR screening, it was not included in this study. Considering data availability and the considerations described above, oil viscosity, gravity, and saturation data were analyzed in this study.

Figure 4 show data distribution of HC gas miscible depending on start year of EOR applications in onshore and offshore environment. Reservoir and oil candidates for EOR application can change with development of EOR technologies and oil industry conditions as time goes passes. These graphs can provide trends data distributions of EOR application and cases out of general ranges. Considering environmental differences from onshore, inclusion of these cases to screening criteria may not appropriate. So, these cases were cautiously removed based on the analysis of these graphs. Figure 4a shows one successful onshore HC gas miscible case (Judy Creek B Pool in Canada) with relatively high oil viscosity compared with other cases. There is no definite trend in high oil viscosity with time of project implementation, and most HC gas miscible applications in offshore fields have been applied to low viscosity and light oil conditions. HC gas miscible application to high oil viscosity offshore fields is unlikely, but possible, considering that the miscibility mechanism can reduce oil viscosity 
and there is successful field application in this condition. Thus, this case was retained for setting the screening criteria. In Figure 4c, offshore EOR were applied to the condition of lower oil saturation than onshore cases.

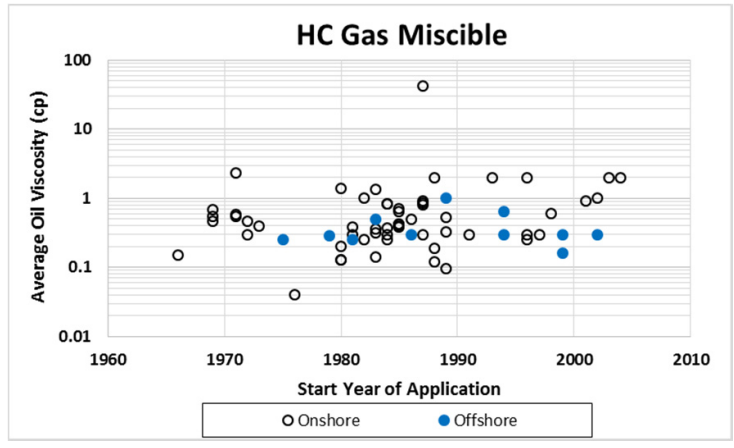

(a)

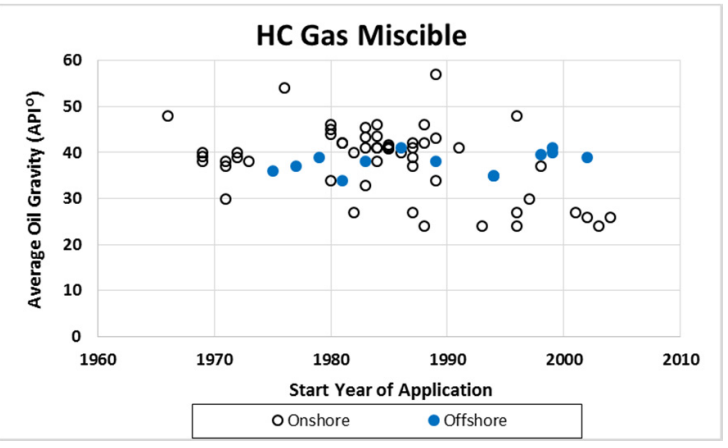

(b)

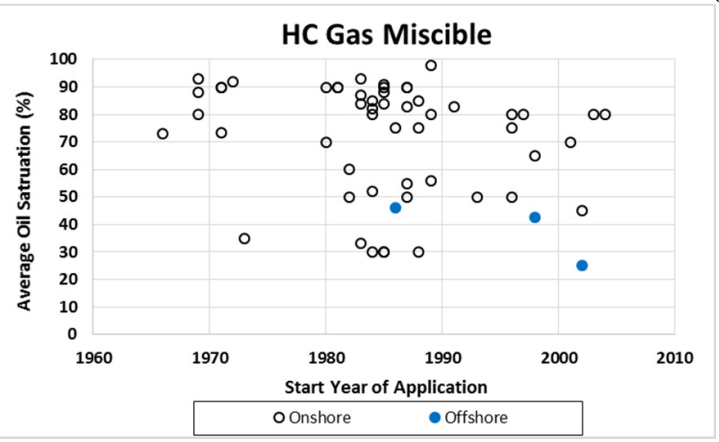

(c)

Figure 4. Application data for $\mathrm{HC}$ gas miscible processes by start year of application. (a) Oil viscosity; (b) Oil gravity; (c) Oil saturation.

To set the new screening criteria (given in Table 3), we updated the boundary values given in Table 2 for oil viscosity, gravity, and saturation based on our analysis (Figure 4). Generally-accepted criteria for reservoir thickness is "thin unless dipping" and it was retained in Table 3. The dipping structure of a reservoir can lead to gravity-stable displacement by the injectant, while gravity override often occurs in thick reservoirs. Although a homogeneous reservoir is a better gas EOR target than a heterogeneous reservoir due to gas channeling, heterogeneous cases in Ekofisk (naturally-fractured reservoir) and Snorre field (high-permeability contrast) were successful [33-37]. Therefore, previously-suggested screening criteria of reservoir permeability, which is "homogeneous", was modified to "homogeneous preferred". Injectant channeling often occurs through high-permeability layers in a heterogeneous reservoir, reducing the volumetric sweep efficiency drastically. Oil composition and reservoir pressure relate to the minimum miscible pressure (MMP) of oil. Even though this aspect could not be analyzed quantitatively, as mentioned above,

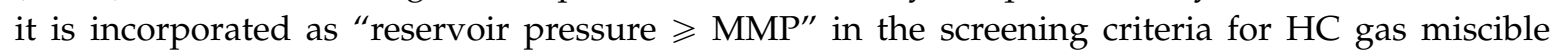
processes. Reservoir pressure at start EOR operation can be more meaningful than initial pressure because injected HC gas contacting with oil in the pressure above MMP is favorable condition for miscibility achievement.

\subsection{Screening Criteria for HC Gas Injection}

Table 3 summarizes the new constraints for offshore application of the HC gas miscible process. For offshore fields, injectant availability is a critical factor, as it constitutes a high proportion of the project cost. Since a large volume of gas injectant is generally required for all gas EOR processes, the on-site produced HC gas is the preferred EOR injectant option offshore, even though large 
compression capacity to handle the produced gas is required. When well-established infrastructure is available, such as in the North Sea and the Gulf of Mexico, injectant transportation from nearby fields is possible. HC gas is also a valuable resource for sale, so the main driving force for offshore HC gas injection applications may be high HC gas availability, the unavailability of a profitable market for the produced HC gas and lack of infrastructure to take the gas onshore. According to Awan et al. [20], $\mathrm{HC}$ gas injection in the North Sea was initiated because of the limited gas-export capacities.

Table 3. New screening criteria for the HC gas miscible process.

\begin{tabular}{|c|c|c|c|c|}
\hline \multicolumn{5}{|c|}{ Screening Criteria by Oil and Reservoir Properties } \\
\hline & Parameters & & EOR Screening Criteria & \\
\hline & Oil Viscosity $(\mathrm{cP})$ & & $\leqslant 42.0$ & \\
\hline & Oil Gravity $\left({ }^{\circ} \mathrm{API}\right)$ & & $\geqslant 24.0$ & \\
\hline & Oil Saturation $(\%)$ & & $\geqslant 25.0$ & \\
\hline & Reservoir Pressure & & $\geqslant \mathrm{MMP}$ & \\
\hline & eservoir Permeability & & Homogeneous Preferred & \\
\hline & servoir Net Thickness & & Thin Unless Dipping & \\
\hline \multicolumn{5}{|c|}{ Screening Considerations by Offshore Constraints } \\
\hline Constraints & Injectant & Disposal & Production & HSE \\
\hline Remote location & $\begin{array}{l}\text { on-site produced HC gas preferred } \\
\text { unavailability of profitable market for } \\
\text { HC gas } \\
\text { compatible water requirement } \\
\text { (in case of WAG) } \\
\text { maximum allowable dilution }\end{array}$ & - & - & - \\
\hline Expensive well & - & - & plans for early gas breakthrough & - \\
\hline $\begin{array}{l}\text { Limited space, } \\
\text { weight }\end{array}$ & $\begin{array}{l}\text { water and gas injection facilities } \\
\text { (in case of WAG) }\end{array}$ & - & $\begin{array}{l}\text { large fluid separation and gas } \\
\text { compression capacity }\end{array}$ & - \\
\hline Subsurface system & $\begin{array}{l}\text { asphaltene mitigation } \\
\text { hydrate mitigation } \\
\text { (in case of WAG) }\end{array}$ & - & $\begin{array}{l}\text { wax mitigation } \\
\text { asphaltene mitigation } \\
\text { hydrate mitigation }\end{array}$ & - \\
\hline
\end{tabular}

HSE: Health, Safety and Environmental.

In the Ekofisk field, there are hydrate formation problems around the injector during the pilot test [35]. HC hydrate is one of the major flow assurance issues in offshore fields. When the conditions of subsea pipeline gas transport (temperature, pressure, and gas composition) are inside the hydrate formation envelope, gas flow rate in sub-sea facilities can decrease significantly owing to hydrate formation. Asphaltene deposition has the potential to decrease gas injectivity significantly. Under normal reservoir conditions, asphaltene is fully dissolved in reservoir oil. However, the equilibrium asphaltene state can be disturbed by an oil composition change caused by gas miscible processes, and asphaltene deposition can occur leading to decreasing injectivity [38] and oil productivity. High flow rates in the production system can also cause a wax deposition problem [39]. Oil temperature is the most important factor affecting wax precipitation and deposition, owing to its direct relationship to the solubility of paraffin in oil, and it has been a major flow assurance issue in low-temperature locations such as subsea production systems and pipelines. Sudden depressurization due to high $\mathrm{HC}$ flow rates in risers causes the gas to come out of solution, reducing the flow temperature and increasing the likelihood of wax deposition at the inner wall of pipes, reducing their effective diameter and increasing pressure loss. Asphaltene and wax deposition are also constraints in onshore fields, but pipeline displacement or deposition mitigation in offshore environments require much higher cost and operational consideration considering sea depth, high cost of offshore operation, and HSE. Although these depositions can induce shutdown or delay field projects, pressure and temperature for hydrate, asphaltene, and wax deposition were only included in screening considerations because these issues are manageable if proper mitigation methods are prepared.

For WAG, injection facilities for water and gas are required and injection water must be compatible with formation water. Otherwise, injectivity may decrease owing to clay swelling, deflocculation, 
and scale deposition problems. While details of these depositional problems during HC gas injection are not generally reported in offshore fields, these flow assurance problems can easily cause project shutdown in offshore fields because the replacement and maintenance of sub-sea facilities is very costly. Considering that asphaltene and wax depositions are common issues for offshore fields, early prediction and mitigation plans are required for offshore HC gas injection applications. Additionally, because of the high uncertainties in the reservoir characterization of offshore fields compared with onshore fields, there is a high possibility of early gas breakthrough, and a contingency plan for this eventuality is needed.

Produced gas includes not only $\mathrm{HC}$ gas but also $\mathrm{CO}_{2}, \mathrm{~N}_{2}$, etc., which have different values of MMP. Miscible conditions require higher pressures than the MMP, and a sufficiently high flow rate, but the amount of $\mathrm{HC}$ gas required for the target flow rate may not available. Thus, the maximum allowable dilution of the injectant, considering the MMP, is needed.

\section{4. $\mathrm{CO}_{2}$ Miscible Process}

The $\mathrm{CO}_{2}$ miscible process is a well-proven technology worldwide, predominantly in onshore fields. Since the MMP of $\mathrm{CO}_{2}$ is generally lower than $\mathrm{HC}$ gas, the $\mathrm{CO}_{2}$ miscible process has a wider range of potential field candidates. In view of the current active interests in seeking synergy between $\mathrm{CO}_{2}$ storage and the proven effectiveness of $\mathrm{CO}_{2} \mathrm{EOR}$, this process has high potential for offshore EOR application. There are two pilot cases of $\mathrm{CO}_{2}$ injection in Lula field and Rang Dong field [40,41]. These cases provide valuable $\mathrm{CO}_{2}$ application experiences. However, the miscibility achievement in these fields is not clear. These data of Lula and Rang Dong field are only used for setting screening considerations.

\subsection{Data Analysis}

Table 4 shows the previously suggested screening criteria for the $\mathrm{CO}_{2}$ miscible process. These criteria have focused on onshore EOR. Screening parameters are similar to those for the HC gas miscible process. As for the HC gas miscible process, the oil viscosity, gravity, and saturation data were analyzed, as shown in Figure 5. As temperature mainly relates to the miscibility condition, it was incorporated into "reservoir pressure $\geqslant M M P$ " criterion, as are oil composition and reservoir pressure. There are other screening criteria considering operations. According to Todd and Grand [42], the reservoir should not have been subject to prior hydrocarbon tertiary recovery to avoid the complexibility and different miscibility of mixed $\mathrm{CO}_{2}$-hydrocarbon gas injection process for $\mathrm{CO}_{2}$-EOR application. According to Bachu [26], commingled reservoirs are not suitable for $\mathrm{CO}_{2}$-EOR for the evident reason that production takes place from more than one oil reservoir and conformance would be extremely difficult to achieve. These criteria are quite reasonable and were included in screening criteria suggested by this paper. There are other criteria that are original oil in place, remaining oil fraction in the reservoir and remaining oil fraction in the reservoir. These criteria highly depends on economic conditions and were not included in this screening criteria considering quickly changing situation of oil industry. Bachu [26] concluded that porosity has almost no effect on feasibility study of $\mathrm{CO}_{2}$ application because most reservoirs would normally satisfy these criteria. In our database, porosity range of successful $\mathrm{CO}_{2}$ application is $4 \%-29.5 \%$. We could not find suitability of porosity for screening criteria and porosity was not included. Initial pore pressure gradient is an important parameter for $\mathrm{CO}_{2}$ storage rather than $\mathrm{CO}_{2} \mathrm{EOR}$.

As shown in Figure 5, the $\mathrm{CO}_{2}$ miscible process has commonly been implemented in light oil with low viscosity conditions and oil saturation higher than $30 \%$, although Figure $5 \mathrm{c}$ shows one case (Olive field in USA) with an oil saturation lower than $20 \%$. As $\mathrm{CO}_{2}$ miscible EOR can decrease residual oil saturation significantly, this case was retained in the quantitative criteria. To set the new screening criteria (given in Table 5), boundary values of oil viscosity, gravity, and saturation are applied based on the analysis given in Figure 5. 
Table 4. Previously-suggested screening criteria for the $\mathrm{CO}_{2}$ miscible process.

\begin{tabular}{|c|c|c|c|c|c|c|}
\hline Parameters & $\begin{array}{c}\text { Reference } \\
{[26]}\end{array}$ & $\begin{array}{c}\text { Reference } \\
{[28]}\end{array}$ & $\begin{array}{l}\text { Reference } \\
\text { [29] }\end{array}$ & $\begin{array}{c}\text { Reference } \\
{[30]}\end{array}$ & $\begin{array}{c}\text { Reference } \\
\text { [31] }\end{array}$ & $\begin{array}{c}\text { Reference } \\
\text { [43] }\end{array}$ \\
\hline Oil viscosity (cP) & $\geqslant 0.4$ and $\leqslant 6$ & $<12$ & $<15$ & $<10$ & $<10$ & $<15$ \\
\hline Oil gravity $(\mathrm{cP})$ & $\geqslant 22$ and $\leqslant 45$ & $>26^{\mathrm{a}}$ & $>25$ & $>22$ & $>22$ & $>25$ \\
\hline Oil composition & 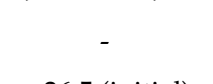 & - & $\begin{array}{l}\text { high } \% \text { of } \\
\mathrm{C}_{5}-\mathrm{C}_{12}\end{array}$ & $\begin{array}{l}\text { high } \% \text { of } \\
\mathrm{C}_{5}-\mathrm{C}_{12}\end{array}$ & - & $\begin{array}{l}\text { high \% of } \\
\mathrm{C}_{5}-\mathrm{C}_{12}\end{array}$ \\
\hline Oil saturation (\%) & $\begin{array}{l}\geqslant 26.5 \text { (initial) } \\
\geqslant 5 \text { (initial pore } \\
\text { space oil } \\
\text { saturation) }\end{array}$ & $>25$ & $>30$ & $>20$ & $>25$ & $>25$ \\
\hline Depth (ft) & $\begin{array}{l}\geqslant 1600 \text { and } \\
\leqslant 13,365\end{array}$ & - & $>2000$ & $\begin{array}{l}\text { varies with } \\
\text { depth }\end{array}$ & $>1970$ & $>2500$ \\
\hline Temperature $\left({ }^{\circ} \mathrm{F}\right)$ & $\geqslant 82$ and $\leqslant 260$ & - & - & - & $>86$ & - \\
\hline Porosity $(\%)$ & $\geqslant 3$ and $\leqslant 37$ & - & - & - & - & - \\
\hline Permeability (md) & - & homogeneous & - & - & - & - \\
\hline Net thickness (ft) & - & thin & $\begin{array}{l}\text { thin unless } \\
\text { dipping }\end{array}$ & $\begin{array}{l}\text { thin unless } \\
\text { dipping }\end{array}$ & - & wide range \\
\hline $\begin{array}{l}\text { Reservoir pressure } \\
\quad(\mathrm{psi})\end{array}$ & $\geqslant \mathrm{MMP}$ & - & $\geqslant \mathrm{MMP}$ & $\begin{array}{lll}11 & 0\end{array}$ & $\geqslant \mathrm{MMP}$ & $\geqslant \mathrm{MMP}$ \\
\hline $\begin{array}{l}\text { Initial pore pressure } \\
\text { gradient }\end{array}$ & $<\operatorname{Grad}\left(\mathrm{S}_{\min }\right)$ & - & - & - & - & - \\
\hline Gas cap & - & - & - & - & no & no \\
\hline $\begin{array}{l}\text { Already undergoing } \\
\text { EOR }\end{array}$ & no & - & - & - & - & - \\
\hline Commingled & no & - & - & - & - & - \\
\hline $\begin{array}{l}\text { Original oil in place } \\
\text { (MMSTB) }\end{array}$ & $\geqslant 12.5$ & - & - & - & - & - \\
\hline $\begin{array}{l}\text { Remaining oil fraction } \\
\text { in the reservoir }(\%)\end{array}$ & $\geqslant 20$ & - & - & - & - & - \\
\hline $\begin{array}{l}\text { Remaining oil fraction } \\
\text { in the reservoir } \\
\text { (MMSTB) }\end{array}$ & $\geqslant 5$ & - & - & - & - & - \\
\hline
\end{tabular}

a: excluding California, oil is $>30^{\circ}$ API; $S_{\min }=$ minimum stress.

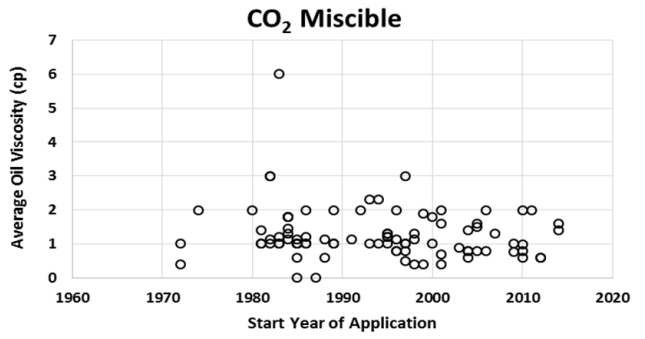

(a)

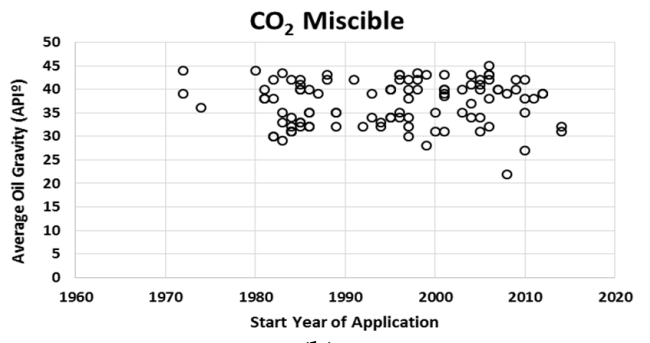

(b)

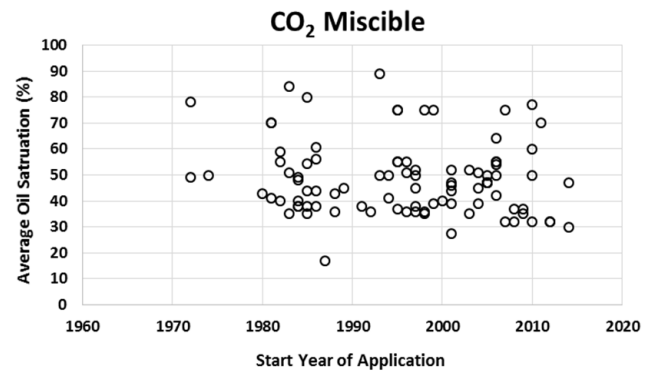

(c)

Figure 5. Application data for the $\mathrm{CO}_{2}$ miscible process by start year of application. (a) Oil viscosity; (b) Oil gravity; (c) Oil saturation. 
Table 5. New screening criteria for the $\mathrm{CO}_{2}$ miscible process.

\begin{tabular}{|c|c|c|c|c|}
\hline \multicolumn{5}{|c|}{ Screening Criteria by Oil and Reservoir Properties } \\
\hline \multicolumn{2}{|r|}{ Parameters } & \multicolumn{3}{|c|}{ EOR Screening Criteria } \\
\hline \multicolumn{2}{|r|}{ Oil viscosity (cP) } & \multicolumn{3}{|c|}{$\leqslant 6.0$} \\
\hline \multicolumn{2}{|r|}{ Oil gravity $\left({ }^{\circ} \mathrm{API}\right)$} & \multicolumn{3}{|c|}{$\geqslant 22.0$} \\
\hline \multicolumn{2}{|r|}{ Oil saturation (\%) } & \multicolumn{3}{|c|}{$\geqslant 17.0$} \\
\hline \multicolumn{2}{|c|}{ Reservoir pressure } & \multicolumn{3}{|c|}{$\geqslant \mathrm{MMP}$} \\
\hline \multicolumn{2}{|c|}{ Reservoir permeability } & \multicolumn{3}{|c|}{ homogeneous preferred } \\
\hline \multicolumn{2}{|c|}{ Reservoir net thickness } & \multicolumn{3}{|c|}{ thin unless dipping } \\
\hline \multicolumn{2}{|c|}{ Commingled } & \multicolumn{3}{|c|}{ No 110} \\
\hline \multicolumn{2}{|c|}{ Already undergoing EOR } & \multicolumn{3}{|c|}{ No } \\
\hline \multicolumn{5}{|c|}{ Screening Considerations by Offshore Constraints } \\
\hline Constraints & Injectant & Disposal & Production & HSE \\
\hline Remote location & $\begin{array}{c}\text { nearby } \mathrm{CO}_{2} \text { source or separation } \\
\text { of } \mathrm{CO}_{2} \text { from produced gas } \\
\text { preferred } \\
\text { compatible water requirement } \\
\text { (in case of WAG) } \\
\text { maximum allowable dilution }\end{array}$ & $\begin{array}{l}\text { disposal in } \\
\text { reservoir } \\
\text { preferred }\end{array}$ & - & $\begin{array}{c}\text { special } \\
\text { evacuation plan } \\
\text { monitoring of } \\
\mathrm{CO}_{2} \text { leaking }\end{array}$ \\
\hline Expensive well & - & - & $\begin{array}{l}\text { plans for early gas } \\
\text { breakthrough }\end{array}$ & - \\
\hline $\begin{array}{l}\text { Limited space, } \\
\text { weight }\end{array}$ & $\begin{array}{l}\text { water and gas injection facilities } \\
\text { (in case of WAG) }\end{array}$ & $\begin{array}{l}\text { disposal in } \\
\text { reservoir } \\
\text { preferred }\end{array}$ & $\begin{array}{l}\text { large fluid separation and gas } \\
\text { compression capacity }\end{array}$ & - \\
\hline \multirow{3}{*}{ Subsurface system } & $\begin{array}{l}\text { corrosion mitigation } \\
\text { asphaltene mitigation }\end{array}$ & \multirow{3}{*}{-} & $\begin{array}{l}\text { wax mitigation } \\
\text { corrosion mitigation }\end{array}$ & \\
\hline & hydrate mitigation & & asphaltene mitigation & - \\
\hline & material compatibility & & hydrate mitigation & \\
\hline
\end{tabular}

\subsection{Screening Criteria and Consideration for $\mathrm{CO}_{2}$ Miscible process}

$\mathrm{CO}_{2}$ is more difficult to obtain offshore than $\mathrm{HC}$ gas, and its economical availability is a critical issue. In view of the usually remote locations of offshore fields, unless there is a nearby $\mathrm{CO}_{2}$ source, $\mathrm{CO}_{2}$ separation from the produced gas is the preferred option. In the pilot case in Lula field, offshore Brazil, $\mathrm{CO}_{2}$ in produced gas was separated and injected with a concentration higher than $80 \mathrm{~mol} \%$.

There are additional consideration of facilities and operation if $\mathrm{CO}_{2}$ concentration in produced gas is high. $\mathrm{CO}_{2}$ is a weak acidic gas and becomes corrosive when dissolved in water. It is known that $\mathrm{CO}_{2}$ is 20 times more soluble than $\mathrm{HC}$ gas in water [44]. For $\mathrm{CO}_{2}$-WAG applications, corrosion prevention needs to be evaluated for all $\mathrm{CO}_{2}$-containing facilities. Injecting and back-produced $\mathrm{CO}_{2}$ need to be dehydrated to avoid corrosion and hydrate formation. Corrosion resistance alloy (CRA) is an effective but expensive solution for $\mathrm{CO}_{2}$-induced corrosion. However, stress corrosion cracking of CRA can occur if $\mathrm{O}_{2}, \mathrm{H}_{2} \mathrm{~S}$, or elemental sulfur is present. Selection of the CRA material is a major issue.

The solubility of $\mathrm{CO}_{2}$ in water can adversely affect oil recovery. Low to moderate water hardness is desirable to prevent adverse $\mathrm{CO}_{2}$ solubility effects from forming $\mathrm{CO}_{2}$ slugs in WAG [45]. Additionally, because supercritical $\mathrm{CO}_{2}$ is a good solvent that degrades the integrity of elastomers used in facilities, more durable and compatible materials must be installed.

In addition to $\mathrm{CO}_{2}$ storage benefits, another benefit of separating $\mathrm{CO}_{2}$ from produced gas and using it for $\mathrm{CO}_{2} \mathrm{EOR}$ is the increase in $\mathrm{HC}$ gas flaring efficiency due to decreases in the $\mathrm{CO}_{2}$ concentration. According to Goodyear et al. [44], $\mathrm{CO}_{2}$ has the potential to cause very low temperatures in HC gas flares, and blowdown and drain systems, due to a strong Joule-Thompson effect. Unburned $\mathrm{HC}$ gas accumulates around the jack-up rig and the adjacent production facility and it may cause fire or an explosion [46]. Depressurization of dense-phase $\mathrm{CO}_{2}$ can lead to extremely low temperatures (as low as $-78{ }^{\circ} \mathrm{C}$ at atmospheric pressure). Solid $\mathrm{CO}_{2}$ can form, leading to potential blockages and over-pressurization of conventional flare systems. 
Owing to the high density of $\mathrm{CO}_{2}$ compared with air, sea evacuation might not be appropriate in case of a $\mathrm{CO}_{2}$ leak. A $\mathrm{CO}_{2}$ concentration of 2 to $5 \mathrm{~mol} \%$ can affect vessel crews and can cause diesel engines to stall, resulting in loss of vessel control. $\mathrm{CO}_{2}$ may present a personnel hazard even at lower concentrations; the short-term exposure limit is $0.5 \%$ by volume. At concentrations approaching $10 \%$ by volume, a rapid loss of consciousness is likely, and at $40 \%$, instantaneous death through asphyxiation is likely [47]. Therefore, monitoring of $\mathrm{CO}_{2}$ leaks and special evacuation plans are needed. These considerations are particularly important for offshore $\mathrm{CO}_{2} \mathrm{EOR}$, with its severe operational space constraints.

\section{Polymer Process}

The polymer process in offshore fields has predominantly been applied in Bohai Bay, offshore China. Additionally, successful pilots in the Captain Field (North Sea) has been reported. Since the polymer process has been proven by onshore applications, it has high potential for offshore applications.

\subsection{Data Analysis}

Table 6 shows previously suggested screening criteria for the polymer process. Based on data availability and the relevant polymer EOR characteristics, the formation type, oil viscosity, gravity, reservoir temperature, and permeability were analyzed.

Table 6. Previously-suggested screening criteria for the polymer process.

\begin{tabular}{|c|c|c|c|c|c|}
\hline Parameters & Reference [21] & Reference [29] & Reference [30] & Reference [31] & Reference [43] \\
\hline Oil Viscosity $(\mathrm{cP})$ & $<200$ & $<20$ & $<150$ & $<150$ & $<100$ \\
\hline Oil Gravity (cP) & - & $>25$ & $>15$ & - & $>22$ \\
\hline Oil Saturation (\%) & - & $>10$ & $>50$ & $>60$ & $>50$ \\
\hline Salinity (ppm) & $<100,000$ & $<100,000$ & - & $<100,000$ & $<100,000$ \\
\hline Hardness (ppm) & $<500$ & - & - & $<1000$ & $<5000$ \\
\hline Wettability & - & $\begin{array}{l}\text { water-wet } \\
\text { preferred }\end{array}$ & - & - & - \\
\hline Depth (ft) & - & $<9000$ & $<9000$ & - & $<9000$ \\
\hline Formation Type & - & $\begin{array}{l}\text { sandstone } \\
\text { preferred }\end{array}$ & $\begin{array}{l}\text { sandstone } \\
\text { preferred }\end{array}$ & - & $\begin{array}{l}\text { sandstone } \\
\text { preferred }\end{array}$ \\
\hline Temperature $\left({ }^{\circ} \mathrm{F}\right)$ & $<200$ & $<200$ & $<200$ & $<158$ & $<200$ \\
\hline Permeability (md) & $>10$ & $>20$ & $>10$ & $>50$ & $>50$ \\
\hline Porosity (\%) & - & $\geqslant 20$ & - & - & - \\
\hline Net Thickness (ft) & - & $>10$ & - & - & - \\
\hline Water Drive & - & - & - & no ${ }^{a}$ & no ${ }^{a}$ \\
\hline GOR & - & - & - & $<10$ & - \\
\hline
\end{tabular}

a: with no gas cap.

While very small pore sizes cause polymer entrapment, leading to low polymer injectivity, the average porosity that is generally reported cannot reflect the full extent of polymer trapping possibilities. Therefore, porosity was not considered when setting screening criteria. Residual oil saturation data is more important for polymer application than average oil saturation at start point of polymer flooding because general targeted oil of polymer flooding is bypassed oil. However, most field data about residual oil saturation was not available and very different depending on reservoir. Although viscoelastic property of EOR polymer can decrease residual oil saturation, there are different opinions about how viscoelastic property of polymer works for decreasing residual oil saturation. Specific criteria of oil saturation closely relates with economics, screening criteria about oil saturation was changed to "oil saturation > residual oil saturation". Most polymer cases have been implemented in sandstone (or loosely-consolidated sand) reservoirs, as shown in Figure 6 . The formation type for all offshore cases is sandstone, owing to concerns over the high retention of polymers in carbonate reservoirs. 
Figure 7a shows two onshore cases with much higher oil viscosity than other cases; these are the Pelican Lake cases. Maximum oil viscosity in the Pelican Lake field is approximately 40,000 cP [48]. Such ultra-high oil viscosity may cause injectivity problems. Considering the long injection lines in cold sub-sea conditions and the high costs in offshore fields, these cases were not considered when setting the screening criteria. Except for the Pelican Lake cases, polymer processes in offshore fields were applied under high oil viscosity conditions compared with onshore cases and the previously-suggested screening criteria. Four offshore fields, offshore China, use a newly developed hydrophobically-associating polymer, which has a high salinity tolerance and stability of shear degradation. Considering these cases, screening criteria for the polymer process could be widened as polymer technology develops. Figure $7 \mathrm{~b}$ shows a trend in polymer applications toward heavier oil reservoirs in recent years, and offshore applications are also for heavier oil conditions than most early onshore cases. Figure $7 \mathrm{~d}$ shows that offshore applications of the polymer process exist in high permeability conditions.

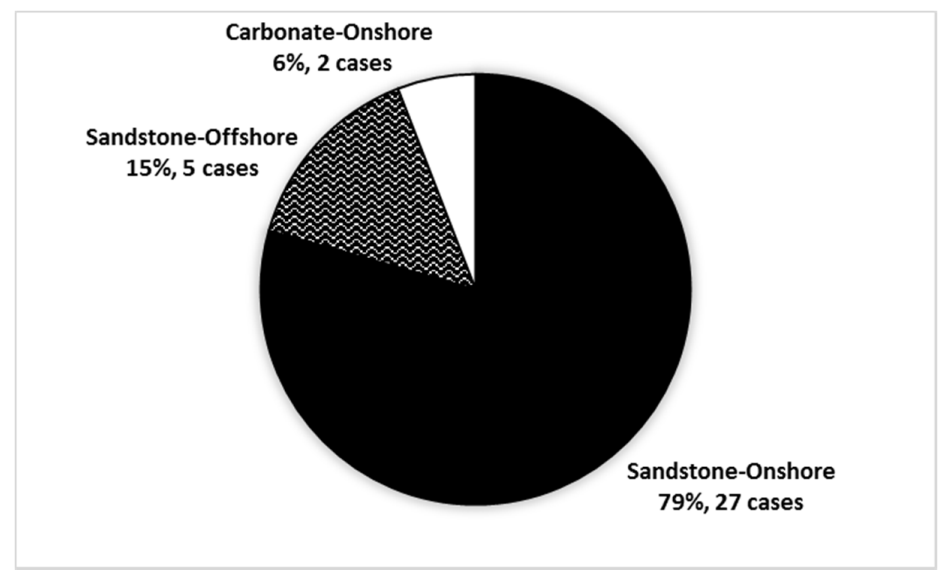

Figure 6. Formation type of polymer applications in onshore and offshore fields.

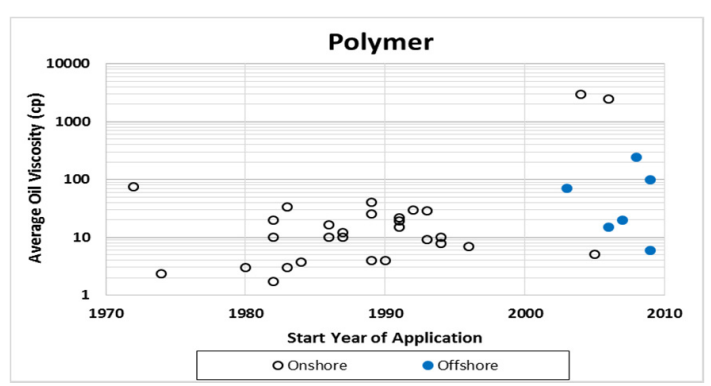

(a)

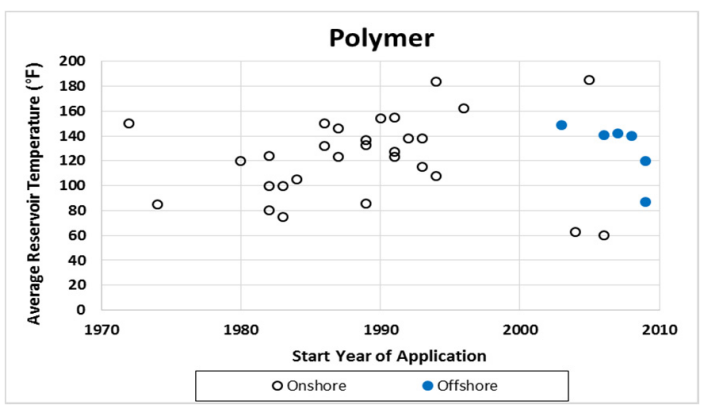

(c)

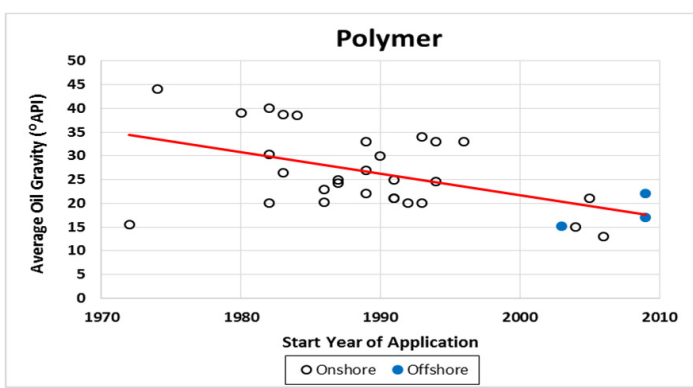

(b)

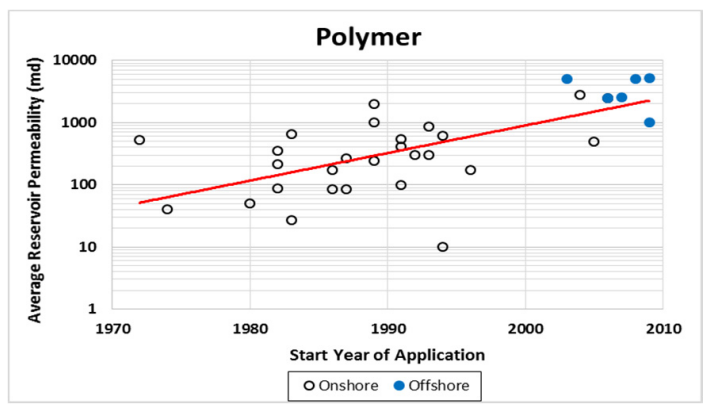

(d)

Figure 7. Application data for the polymer process by start year of application. (a) Oil viscosity; (b) Oil gravity; (c) Reservoir temperature; (d) Reservoir permeability. 
Water salinity and hardness can critically affect the feasibility of polymer injection because polymer viscosity drastically decreases with increases in salinity and hardness. Above a critical hardness level, polymers can precipitate causing formation damage. Formation salinity and hardness data are only available for three offshore cases, as shown in Table 7. The salinity and hardness of these cases in China are low compared with general offshore field. There is one polymer application case in offshore environment which is not included in Table 1. In Dalia Field (Angola), salinity is up to 93,900 ppm and hardness is $21,300 \mathrm{ppm}$ but production responses have not yet been reported due to long well space.

Table 8 shows the new screening criteria, with the boundary values updated as analyzed in Figure 7.

Table 7. Salinity and hardness of offshore fields.

\begin{tabular}{ccc}
\hline Field & Salinity $(\mathbf{p p m})$ & Hardness $(\mathbf{p p m})$ \\
\hline PF-A & $6540-20,000$ & $30-800$ \\
PF-B & 2873 & 10 \\
PF-C & $3000-6500$ & 13 \\
\hline
\end{tabular}

Table 8. New screening criteria for the polymer process.

\begin{tabular}{|c|c|c|c|c|}
\hline \multicolumn{5}{|c|}{ Screening Criteria by Oil and Reservoir Properties } \\
\hline \multicolumn{3}{|c|}{ Parameters } & \multicolumn{2}{|c|}{ EOR Screening Criteria } \\
\hline \multicolumn{3}{|c|}{ Formation type } & \multicolumn{2}{|c|}{ sandstone preferred } \\
\hline \multicolumn{3}{|c|}{ Oil viscosity $(\mathrm{cP})$} & \multicolumn{2}{|c|}{$\leqslant 240.0$} \\
\hline \multicolumn{3}{|c|}{ Oil gravity $\left({ }^{\circ} \mathrm{API}\right)$} & \multicolumn{2}{|l|}{$\geqslant 15.2$} \\
\hline \multicolumn{3}{|c|}{ Oil saturation $(\%)$} & \multicolumn{2}{|c|}{ >residual oil saturation } \\
\hline \multicolumn{3}{|c|}{ Reservoir temperature $\left({ }^{\circ} \mathrm{F}\right)$} & \multicolumn{2}{|c|}{$\leqslant 185.0$} \\
\hline \multicolumn{3}{|c|}{ Reservoir permeability } & \multicolumn{2}{|l|}{$\geqslant 10$} \\
\hline \multicolumn{3}{|c|}{ Salinity of formation water (ppm) } & \multicolumn{2}{|l|}{$\leqslant 20,000$} \\
\hline \multicolumn{3}{|c|}{ Hardness of formation water (ppm) } & \multicolumn{2}{|l|}{$\leqslant 800$} \\
\hline \multicolumn{5}{|c|}{ Screening Considerations by Offshore Constraints } \\
\hline Constraints & Injectant & Disposal & Production & HSE \\
\hline \multirow[t]{2}{*}{ Remote location } & $\begin{array}{l}\text { compatible water with low } \\
\text { salinity and hardness } \\
\text { requirement } \\
\text { preparation of homogeneous }\end{array}$ & $\begin{array}{l}\text { recycling of } \\
\text { produced } \\
\text { polymer }\end{array}$ & $\begin{array}{l}\text { on-site fluid } \\
\text { separation preferred }\end{array}$ & \multirow[t]{2}{*}{ biocide } \\
\hline & $\begin{array}{l}\text { polymer solution with } \\
\text { minimum impurities } \\
\text { large storage capacity preferred }\end{array}$ & $\begin{array}{l}\text { reinjection of } \\
\text { produced water } \\
\text { with polymer }\end{array}$ & powdered polymer & \\
\hline Expensive well & $\begin{array}{l}\text { polymer with long-duration } \\
\text { stability required }\end{array}$ & - & - & - \\
\hline $\begin{array}{l}\text { Limited space, } \\
\text { weight }\end{array}$ & $\begin{array}{l}\text { individual unit preferred } \\
\text { fast hydration of polymer }\end{array}$ & $\begin{array}{l}\text { overboarding } \\
\text { poorly } \\
\text { biodegradable } \\
\text { polymer }\end{array}$ & $\begin{array}{l}\text { emulsion mitigation } \\
\text { with consideration of } \\
\text { polymer precipitation }\end{array}$ & $\begin{array}{l}\text { individual unit } \\
\text { preferred }\end{array}$ \\
\hline Subsurface system & polymer shear degradation & - & - & - \\
\hline
\end{tabular}

\subsection{Screening Criteria and Consideration for Polymer Process}

Owing to the strong influence on viscosity of partially-hydrolyzed polyacrylamide (PHPA), which is the most widely used EOR polymer, injection water with low salinity and low hardness is needed, as too high a cation concentration may increase the possibility of scale deposition. Cation concentrations in seawater and typical formation water in offshore fields are high. Considering the problems of clay swelling, deflocculation, and scale deposition, water management is very important for polymer flooding applications in offshore fields. Considering the limited space, weight, and heat availability offshore, conventional thermal-based water desalination techniques, such as multi-stage flash distillation, multi-effect distillation, thermocompression distillation, and mechanical 
vapor compression, are challenging to implement. In contrast, the membrane-based reverse-osmosis method is compact, lightweight, and requires no heat. However, its major disadvantage is that it provides almost fresh water. Too low a cation concentration may increase the possibility of clay swelling and deflocculation. Ayirala et al. [49] suggested a new desalination method that can control the cation concentration of injection water. Xanthan and newly-developed polymers, such as 2-acrylamido-2-methylpropane sulfonic acid (AMPS), poly-vinyl pyrrolidones (PVP), or N-vinyl pyrrolidones, have high tolerance to divalent cations. In the case of these polymer application, high salinity and hardness issues can be mitigated.

For oils with a high acid number, which are found frequently in offshore reservoirs, naphthenic acids in the oil can form very stable emulsions. Polymer addition tends to worsen the emulsion problem, which can be a significant problem owing to the severe constraints on offshore facilities. Some of the injected polymer is produced alongside emulsion and increases the emulsion stability and viscosity [50], leading to a long processing time for emulsion breaking on the platform. To reduce emulsion breaking time, a heating method is usually applied in offshore fields. However, temperatures higher than the cloud point of the polymer causes polymer precipitation. The precipitated polymer can induce heating equipment failures, including heat exchangers and in-vessel heating elements, such as fire tubes. Chemical additions may be needed to elevate the cloud point of produced polymer fluids [51].

PHPA is not sensitive to biodegradation, which is a good factor for performance in reservoirs. However, environmental restrictions limit the overboarding of poorly biodegradable EOR chemicals. Recycling of produced polymer is one possible option considering the remote location from the shore, but the reconstitution of produced polymer for injection is not yet a proven technology and is currently not cost effective. For injection, a homogeneous polymer solution is required because polymer that aggregates in injection solutions can cause injection problems. $\mathrm{Fe}^{2+}$ and $\mathrm{O}_{2}$ in the water can easily degrade PHPA, and often come into contact with the polymer solution during its preparation and transportation. Thus, preparation, transportation, and injection of a homogeneous polymer solution with low impurities $\left(\mathrm{Fe}^{2+}\right.$ and $\left.\mathrm{O}_{2}\right)$ are important. A pressurized inert gas blanket, such as nitrogen, is an effective solution, as is the addition of reducing chemicals; approximately $10 \%$ to $30 \%$ ITW (isopropyl alcohol and thiourea in water) or biocide is sometimes added to polymer solutions to prevent polymer degradation. Although EOR polymers are known as non-toxic materials, disposal of produced polymer with chemical additives must be avoided. Polymers also hinder water-processing separators that are used for water cleanup, and separated polymer water may contain several hundred ppm of dispersed oil. In most parts of world, residual oil-in-water content in overboard water must be $29 \mathrm{ppm}$ or lower [51]. Thus, reinjection of produced water should be considered as a possible option.

Commonly, there are two types of polymer: powder and emulsion. Although emulsion polymers are easier to handle, they involve higher costs than powder polymers. Most offshore fields, including SZ36-1, PF-A, PF-B, PF-C, and Dalia used powder polymers. For powder polymers, space and time are required for mixing and hydration of the dry polymer. Considering the limited space on the platform, fast hydration of polymer is important. Specialized polymer mixing and hydration equipment is needed to reduce the time required for injection polymer solution preparation.

In case of xanthan injection, bioxide is always injected (even in PHPA injection, bioxide is sometimes injected) and the bioxide presence on the offshore platform is one of serious HSE issue. Powdered polymer in the air on the platform can also be a HSE issue. Therefore, the bioxide and polymer powder are needed to be handled and separated from people on the platform.

Shear degradation of polymer near the choke is an important issue in offshore fields. According to Rivas and Gathier [52], between $30 \%$ and $70 \%$ viscosity loss of the polymer solution can occur depending on the choke dimensions and the polymer concentration and type. In order to compensate for this viscosity loss, polymer over-dosing may be required, but this may increase operation expenses significantly. Long well spacing means a long residence time for the polymer in the reservoir, 
increasing the time for which the polymer must be stable under reservoir temperature, salinity, and hardness conditions.

Independent units (a barge, FPSO, or jack-up rig) may reduce the cost of implementation for EOR projects considering the added flexibility of space utilization, opportunities for leasing the required equipment, mobility, and relative ease of operation for EOR facilities by specialist EOR companies [53].

\section{Conclusions}

Considering the large volume of recoverable oil, EOR applications are a highly-promising option for offshore fields. For onshore fields, thermal EOR processes using steam are most common. In addition to thermal EOR, $\mathrm{CO}_{2}$ miscible, $\mathrm{HC}$ gas miscible, and polymer processes are the most widely-used processes onshore. The HC gas miscible process is the most common EOR method for offshore fields. This means that there are unique governing parameters for offshore field EOR applications. Based on a comprehensive analysis of successful EOR cases (327 cases from onshore and 19 cases from offshore), new technical screening criteria for offshore EOR applications are proposed. These criteria consist of quantitative bounds that are imposed on the oil and reservoir properties, and qualitative constraints, including injectant availability, issues related to flow assurance, and HSE issues, that are critical for EOR applications in offshore fields. Screening criteria and considerations for the $\mathrm{CO}_{2}$ miscible, HC gas miscible, and polymer processes, which have high potential for offshore applications, are suggested. Considering that the most common offshore EOR is the HC gas miscible process, owing to the relatively high availability of $\mathrm{HC}$ gas compared with other injectants, economical availability of the injectant is the key issue for offshore fields. In addition to the screening criteria and qualitative considerations presented in this paper, personnel training and mindset is important for all offshore EOR processes, because offshore EOR applications are rare compared with conventional oil production (primary and secondary oil recovery). New skills, including a different operating philosophy, management technique, closer surveillance, quality control, and new processes/equipment must be developed. The results in this research can provide major influential factors, risk factors, and ranges of reservoir and oil properties for applications of $\mathrm{CO}_{2}$ miscible, $\mathrm{HC}$ gas miscible, and polymer processes in deepsea oil fields rather than shallow sea oil fields.

Acknowledgments: This work was supported by the Energy Efficiency \& Resources of the Korea Institute of Energy, Technology, Evaluation, and Planning (KETEP) grant funded by the Korean government Ministry of Trade, Industry and Energy (20122010300020).

Author Contributions: Pan-Sang Kang is the main researcher who collected, analyzed data and organized research in this paper. Jong-Se Lim suggested ideas and gave guidance from a theoretical point of view. Chun Huh gave field experiences for revision of this paper. All authors have given approval to the final version of the manuscript.

Conflicts of Interest: The authors declare no conflict of interest.

\section{References}

1. Lake, L.W. Defining Enhanced Oil Recovery. Enhanced Oil Recovery, 1st ed.; Prentice-Hall: Eaglewood Cliffs, NJ, USA, 1989; pp. 1-16.

2. Wehunt, C.D.; Burke, N.E.; Noonan, S.G.; Bard, T.R. Technical challenges for offshore heavy oil field developments. In Proceedings of the Offshore Technology Conference, Houston, TX, USA, 5-8 May 2003.

3. Bondor, P.L.; Hite, J.R.; Avasthi, S.M. Planning EOR projects in offshore oil fields. In Proceedings of the SPE Latin American and Caribbean Petroleum Engineering Conference, Rio de Janeiro, Brazil, 20-23 June 2005.

4. Manrique, E.; Thomas, C.; Ravikiran, R.; Izadi, M.; Lantz, M.; Romero, J.; Alvarado, V. EOR: Current status and opportunities. In Proceedings of the SPE Improved Oil Recovery Symposium, Tulsa, OK, USA, 24-28 April 2010.

5. Alvarado, V.; Manrique, E. Engineering design challenges and opportunities beyond Waterflooding in Offshore Reservoirs. In Proceedings of the Offshore Technology Conference, Houston, TX, USA, 6-9 May 2013. 
6. Kang, P.S.; Lim, J.S.; Huh, C. Screening criteria for application of EOR processes in offshore fields. In Proceedings of the 24th International Ocean and Polar Engineering Conference, Busan, Korea, 15-20 June 2014.

7. Kang, P.S.; Lim, J.S.; Huh, C. Integrated screening criteria for offshore application of enhanced oil recovery. In Proceedings of SPE Annual Technical Conference and Exhibition, Amsterdam, The Netherlands, 27-29 October 2014.

8. Delamaide, E.; Moreau, P.; Tabary, R.A. New approach for offshore chemical enhanced oil recovery. In Proceedings of the Offshore Technology Conference, Houston, TX, USA, 4-7 May 2015.

9. Oil and Gas Journal, 1996 Worldwide EOR Survey. Available online: http://www.ogj.com/articles/ print/volume-94/issue-16/in-this-issue/general-interest/1996-worldwide-eor-survey.html (accessed on 3 June 2015).

10. Oil and Gas Journal, 1998 Worldwide EOR Survey. Available online: http://www.ogj.com/articles/ print/volume-96/issue-16/in-this-issue/general-interest/1998-worldwide-eor-survey.html (accessed on 3 June 2015).

11. Oil and Gas Journal, 2000 Worldwide EOR Survey. Available online: http://www.ogj.com/ogj-survey -downloads.html (accessed on 3 June 2015).

12. Oil and Gas Journal, 2002 Worldwide EOR Survey. Available online: http://www.ogj.com/ogj-survey -downloads.html (accessed 3 June 2015).

13. Oil and Gas Journal, 2004 Worldwide EOR Survey. Available online: http://www.ogj.com/ogj-survey -downloads.html (accessed on 3 June 2015).

14. Oil and Gas Journal, 2006 Worldwide EOR Survey. Available online: http://www.ogj.com/ogj-survey -downloads.html (accessed on 3 June 2015).

15. Oil and Gas Journal, 2008 Worldwide EOR Survey. Available online: http://www.ogj.com/ogj-survey -downloads.html (accessed on 3 June 2015).

16. Oil and Gas Journal, 2010 Worldwide EOR Survey. Available online: http://www.ogj.com/ogj-survey -downloads.html (accessed on 3 June 2015).

17. Oil and Gas Journal, 2012 Worldwide EOR Survey. Available online: http://www.ogj.com/ogj-survey -downloads.html (accessed on 3 June 2015).

18. Oil and Gas Journal, 2014 Worldwide EOR Survey. Available online: http://www.ogj.com/ogj-survey -downloads.html (accessed on 3 June 2015).

19. Han, M.; Xiang, W.; Zhang, J.; Jiang, W.; Sun, F. Application of EOR technology by means of polymer flooding in Bohai Oilfields. In Proceedings of the International Oil and Gas Conference and Exhibition in China, Beijing, China, 5-7 December 2006.

20. Awan, A.R.; Teigland, R.; Kleppe, J.A. Survey of North Sea enhanced-oil-recovery projects initiated during the years 1975 to 2005. SPE Reserv. Eval. Eng. 2008, 11, 497-512. [CrossRef]

21. Kang, X.; Zhang, J.; Sun, F.; Zhang, F.; Feng, G.; Yang, J.; Zhang, X.; Xiang, W. A review of polymer EOR on offshore heavy oil field in Bohai Bay, China. In Proceedings of the SPE Enhanced Oil Recovery Conference, Kuala Lumpur, Malaysia, 19-21 July 2011.

22. Sun, Y.; Zhao, L.; Lin, T. Enhance offshore heavy oil recovery by Cyclic Steam-Gas-Chemical Co-stimulation. In Proceedings of the SPE Heavy Oil Conference and Exhibition, Kuwait City, Kuwait, 12-14 December 2011.

23. Brodie, J.; Zhang, P.; Hetland, S.M.; Moulds, T.; Jhaveri, B. BP North Sea gas injection projects: Sustaining offshore production. In Proceedings of the Abu Dhabi International Petroleum Conference and Exhibition, Abu Dhabi, UAE, 11-14 November 2012.

24. Dai, Z.; Middleton, R.; Viswanathan, H.; Fessenden-Rahn, J.; Bauman, J.; Pawar, R.; Lee, S.; McPherson, B. An integrated framework for optimizing $\mathrm{CO} 2$ sequestration and enhanced oil recovery. Environ. Sci. Technol. Lett. 2014, 1, 49-54. [CrossRef]

25. Dai, Z.; Viswanathan, H.; Fessenden-Rahn, J.; Middleton, R.; Pan, F.; Jia, W.; Lee, S.; McPherson, B.; Ampomah, W.; Grigg, R. Uncertainty quantification for $\mathrm{CO}_{2}$ sequestration and enhanced oil recovery. Energy Procedia 2014, 63, 7685-7693. [CrossRef]

26. Bachu, $\mathrm{S}$. Identification of oil reservoirs suitable for $\mathrm{CO}_{2}-\mathrm{EOR}$ and $\mathrm{CO}_{2}$ storage (CCUS) using reserves databases, with application to Alberta, Canada. Int. J. Greenh. Gas Control 2015, 44, 152-165. [CrossRef]

27. Lee, J.Y.; Shin, H.J.; Lim, J.S. Selection and evaluation of enhanced oil recovery method using artificial neural network. Geosyst. Eng. 2011, 14, 157-164. [CrossRef] 
28. Brashear, J.P.; Kuuskraa, V.A. The potential and economics of enhanced oil recovery. J. Pet. Technol. 1978, 30, 1231-1239. [CrossRef]

29. Goodlett, G.O.; Honarpour, F.T.; Chung, F.T.; Sarathi, P.S. The role of screening and laboratory flow studies in EOR process evaluation. In Proceedings of the SPE Rocky Mountain Regional Meeting, Billings, MT, USA, 19-21 May 1986.

30. Taber, J.J.; Martin, F.D.; Seright, R.S. EOR Screening criteria revisited-Part: 1 Introduction to screening criteria and enhanced recovery field projects. SPE Reserv. Eng. 1997, 12, 189-198. [CrossRef]

31. Al-Bahar, M.A.; Merrill, R.; Peake, W.; Jumaa, M.; Oskui, R. Evaluation of IOR potential within Kuwait. In Proceedings of the Abu Dhabi International Conference and Exhibition, Abu Dhabi, UAE, 10-13 October 2004.

32. Bourdarot, G.; Ghedan, S. Modified EOR screening criteria as applied to a group of offshore carbonate oil reservoirs. In Proceedings of the SPE Reservoir Characterisation and Simulation Conference and Exhibition, Abu Dhabi, UAE, 9-11 October 2011.

33. Hallenbeck, L.D.; Stylte, J.E.; Ebbs, D.J.; Thomas, L.K. Implementation of the Ekofisk Field Waterflood. SPE Form. Eval. 1991, 6, 284-290. [CrossRef]

34. Blaker, T.; Celius, H.K.; Lie, T.; Martinsen, H.A.; Rasmussen, L.; Vassenden, F. Foam for Gas Mobility Control in the Snorre Field: The FAWAG Project. In Proceedings of the SPE Annual Technical Conference and Exhibition, Houston, TX, USA, 3-6 October 1999.

35. Jensen, T.B.; Harpole, K.J.; Osthus, A. EOR screening for Ekofisk. In Proceedings of the SPE European Petroleum Conference, Paris, France, 24-25 October 2000.

36. Skauge, A.; Aarra, M.G.; Surguchev, L.; Martinsen, H.A.; Rasmussen, L. Foam-assisted WAG: Experience from the Snorre Field. In Proceedings of the SPE/DOE Improved Oil Recovery Symposium, Tulsa, OK, USA, 13-17 April 2002.

37. Aarra, M.G.; Skauge, A.; Martinsen, H.A. FAWAG: A breakthrough for EOR in the North Sea. In Proceedings of the SPE Annual Technical Conference and Exhibition, San Antonio, TX, USA, 29 September-2 October 2002.

38. Oskui, G.P.; Jumaa, M.A.; Abuhaimed, W.A. Laboratory investigation of asphaltene precipitation problems during $\mathrm{CO}_{2}$ /Hydrocarbon Injection Project for EOR application in Kuwaiti Reservoirs. In Proceedings of the Kuwait International Petroleum Conference and Exhibition, Kuwait City, Kuwait, 14-16 December 2009.

39. Rosa, M.; Branco, C. Optimizing $\mathrm{CO}_{2}$ injection in and offshore field considering operational constraints. In Proceedings of the SPE Latin America and Caribbean Petroleum Engineering Conference, Mexico City, Mexico, 16-18 April 2012.

40. Pizarro, J.O.S.; Branco, C.C.M. Challenges in implementing an EOR project in the pre-salt province in Deep Offshore Brasil. In Proceedings of SPE EOR Conference at Oil and Gas West Asia, Muscat, Oman, 16-18 April 2012.

41. Konish, Y.; Takagi, S.; Farag, S.; Ha, V.V.; Hatakeyama, A.; Trung, P.N.; Son, L.N. Fluid saturation monitoring by cased hole logging for $\mathrm{CO}_{2}$ Huff-n-Puff Test in a Vietnam Offshore Field. In Proceedings of the SPE Enhanced Oil Recovery Conference, Kuala Lumpur, Malaysia, 2-4 July 2013.

42. Todd, M.R.; Grand, G.W. Enhanced oil recovery using carbon dioxide. Energy Convers. 1993, 34, 1157-1164. [CrossRef]

43. Alvarado, V.; Ranson, A.; Hernandez, K.; Manrique, E.; Matheus, J. Selection of EOR/ior opportunities based on machine learning. In Proceedings of the European Petroleum Conference, Aberdeen, UK, 29-31 October 2002.

44. Goodyear, S.G.; Koster, M.P.; Marriott, K.A.; Paterson, A.; Sipkema, A.W.; Young, I.M. Moving $\mathrm{CO}_{2} \mathrm{EOR}$ offshore. In Proceedings of the Offshore Europe, Aberdeen, UK, 6-8 September 2011.

45. Ayirala, S.C.; Yousef, A.A. Injection water chemistry requirement guidelines for IOR/EOR. In Proceedings of the SPE Improved Oil Recovery Symposium, Tulsa, OK, USA, 12-16 April 2014.

46. Ha, G.H.; Tran, N.D.; Vu, H.H.; Takagi, S.; Mitsuishi, H.; Hatakeyama, A.; Uchiyama, T.; Ueda, Y.; Nguyen, T.V.; Phan, T.N.; et al. Design and implementation of $\mathrm{CO}_{2}$ Huff-n-Puff operation in a Vietnam Offshore Field. In Proceedings of the Abu Dhabi International Petroleum Conference and Exhibition, Abu 5Dhabi, UAE, 11-14 November 2012.

47. Salim, M.; Harley, J.; Faizal, Z. Process design aspects for taking $\mathrm{CO}_{2}$ enhanced oil recovery offshore. In Proceedings of the SPE EOR Conference at Oil and Gas West Asia, Muscat, Oman, 16-18 April 2012. 
48. Delamaide, E.; Zaitoun, A.; Renard, G.; Tabary, R. Pelican Lake Field: First successful application of polymer flooding in a heavy oil reservoir. In Proceedings of the SPE Enhanced Oil Recovery Conference, Kuala Lumpur, Malaysia, 2-4 July 2013.

49. Ayirala, S.C.; Uehara-Nagamine, E.; Matzakos, A.N.; Chin, R.W.; Doe, P.H.; Hoek, P.J. A designer water process for offshore low salinity and polymer flooding applications. In Proceedings of the SPE Improved Oil Recovery Symposium, Tulsa, OK, USA, 24-28 April 2010.

50. Zheng, F.; Quiroga, P.; Sams, G. Challenges in processing produced emulsion from chemical enhanced oil recovery-polymer flood using polyacrylamide. In Proceedings of the SPE Enhanced Oil Recovery Conference, Kuala Lumpur, Malaysia, 19-21 July 2011.

51. Raney, K.R.; Ayirala, S.; Chin, R.; Verbeek, P. Surface and subsurface requirements for successful implementation of offshore chemical enhanced oil recovery. SPE Prod. Oper. 2012, 27, 294-305. [CrossRef]

52. Rivas, C.; Gathier, F. C-EOR projects-offshore challenges. In Proceedings of the 23rd International Offshore and Polar Engineering Conference, Anchorage, Alaska, 30 June-5 July 2013.

53. Wodehouse, J.; Henthorne, L. The comparative advantages of a dedicated CEOR vessel for offshore field developments. In Proceedings of the SPE Enhanced Oil Recovery Conference, Kuala Lumpur, Malaysia, 19-21 July 2011.

(C) 2016 by the authors; licensee MDPI, Basel, Switzerland. This article is an open access article distributed under the terms and conditions of the Creative Commons by Attribution (CC-BY) license (http://creativecommons.org/licenses/by/4.0/). 